\title{
Analysis of the psychometric characteristics of the experimental psychological methods for the examination of law enforcement officers
}

\author{
Omelyanovich Vitaliy ${ }^{\mathrm{a}, \mathrm{b}}$ \\ ${ }^{a}$ Bogomolets National Medical University, Kyiv, Ukraine \\ ${ }^{b}$ Shupyk National Academy of Postgraduate Education, Kyiv, Ukraine
}

\begin{abstract}
Background. As a number of local documents requires continuous improvement of psychodi-agnostic work, one of the main activities of the Internal Affairs Agencies psychi-atric service is an active clinical examination, the timely detection of law en-forcement officers employees with neuropsychological instability, tendency to aggression and other forms of deviant behavior.
\end{abstract}

Methods. The aim of the study was the selection of additional experimental psychological techniques to conduct psychological examinations of law enforcement officers. As on objective of a study evaluation of reliability, validity and discriminative level of psychological tests has been chosen. The object of study was a group of the randomly selected representatives of almost all the major police professions, consisting of 348 respondents of the male gender in the age from 21 to 48 years old. Given the fact that the screening psychological evaluation of law enforce-ment officers during periodic psychiatric examinations is usually carried out un-der time constraints and the urgency to form an opinion immediately after the end of testing, nonprojective psychological techniques have been chosen for test-ing. These techniques, according to the scientific literature, proved their effective-ness and, in addition, are characterized by a small volume of questions and sim-plicity (largely - the dichotomous scales). Moreover, it does not require a lot of time to handle them: a methodology «Aggressive behavior» (E. P Ilyin, P. O. Ko-valev, 2001), the test «Anxiety-Rigidity- Extravertebral» (D. Moudsli, 2002), the test «IPC-Fragebogen» (H. Levenson, 1986), the test is «MS PTSD» (NM Keane, 2001).

Results. Tests reliability was investigated by determining the consistency of their results by calculating the L. Cronbach's coefficient $\alpha$ and Guttman method of splitting in half; discriminative level was determined by calculating the ratio; construct validi-ty was investigated by the exploratory factor analysis conduction. The factor loadings equal to or greater than 0,3 were considered to be sufficient, provided that the other factor loadings per item tend to zero; the criterion validity was in-vestigated by calculating the dichotomous correlation coefficient, and the statis-tical significance of the coefficient was determined by the distribution tables 2 with one degree of freedom. The data achieved makes it possible to assert that law enforcement officers contingent discriminative level $(\delta$-Ferguson $=0,88 \quad 0,1)$ and the criterion validity $(0,225 ;$ r3E-05) of all the techniques of scales are high enough. Reliability of «Aggressive behavior» methodology is estimated as high only in relation to the general level of diagnosis of incontinence ( $\alpha$-Cronbach $=0,78$; Guttman split-half $=0,763$ ), whereas the reliability and construct validity of its individual scales are insufficient. Taking into account the high level of criteria validity and discrimina-tive level of this test, it is possible to talk about whether it should be used only as an indicator of the overall level of incontinence of internal affairs body employ-ees. «MS PTSD» has revealed a high level of reliability, and discriminative valid-ity $(\alpha$-Cronbach $=0,67$; Guttman split-half $=0,63 ; \delta$-Ferguson $=0,984)$, which allows to recommend its use in the process of psycho-diagnostic survey of law enforcement officers. The level of reliability and construct validity of methods «IPC-Fragebogen» and «ARE» was insufficient ( $\alpha$-Kronbaha0,5; Guttman split-half0,5), indicat-ing that they cannot be used in the process of psychological examinations of law enforcement officers.

Conclusion. Notwithstanding that several diagnostic instruments have proven themselves in long use in other professional contingents, an important conclusion has been ob-tained as a result of the work that the existing practice of these practices intro-duction into the activity of departmental psychological and psychiatric services without holding their quality evaluation and analysis of testing during the exami-nation of law enforcement officers should be considered unacceptable. On the contrary, the use of any psycho-diagnpstic tools must be carried out only after a reasonable proof of the adequacy of their contingent's psychometric characteris-tics, gender, socio-psychological, and, possibly, regional particularities. 


\section{1. Актуальність}

Одним з основних напрямків роботи по психологопсихіатричному забезпеченню службової діяльності працівників органів внутрішніх справ (ОВС) є активна диспансеризація контингенту, прикріпленого до психіатричних лікувально-профілактичних закладів MBC шляхом проведення щорічних періодичних психіатричних оглядів з обов'язковим психологічним скринінговим діагностичним обстеженням. Низка відомчих документів, таких як Програма психопрофілактичної роботи з особовим складом органів та підрозділів внутрішніх справ України на 2013-2017 рр., Концепція розвитку і вдосконалення медико-психологічної реабілітації в системі МВС України та програма заходів з їі реалізації та ін., вимагає постійного вдосконалення психодіагностичної роботи, своєчасного виявлення не тільки осіб, які страждають на розлади психіки та поведінки, але й працівників ОВС з нервово-психічною нестійкістю, схильністю до агресії та інших девіантних форм по-ведінки. Здійснення цієї роботи неможливо без розширення асортименту експериментальнопсихологічних методик, які могли б бути використані під час проведення масових щорічних психологопсихіатричних оглядів працівників ОВС у Центрах психіатричної допомоги та професійного психофізіологічного відбору ГУМВС (УМВС) областей.

Таким чином, метою даного дослідження був відбір додаткових експериментально-психологічних методик для проведення психологічного скринінг-діагностичного обстеження працівників ОВС. Відповідно до поставленої мети, в якості завдань дослідження виступала оцінка надійності, дискримінативності та валідності обраних експериментальнопсихологічних методик та формування висновків щодо можливості їх подальшого використання в системі ОВС України.

\section{2. Методи та матеріали}

3 урахуванням того, що скринінгове психологічне обстеження працівників ОВС під час проведення щорічних періодичних психіатричних оглядів здійснюється в умовах обмеження часу та необхідності винесення висновку безпосередньо після закінчення тестування, для апробації були відібрані непроективні психологічні методики, які добре зарекомендували себе за даними наукової літератури, та, крім того, характеризуються невеликим обсягом запитань (тверджень), простотою відповідей (в більшості - це діхотомічні шкали), а також не потребують великої кількості часу для їх опрацювання. Основними діагностичними цілями обраних психологічних тестів було виявлення різноманітних психологічних маркерів нервовопсихічної нестійкості, як екзогенно-невротичної, так i конституціонально-особистісної етіології.
Методика «Агресивна поведінка» (Є. П. Ільїн, П. О. Ковальов) є струк-турованим психологічним інтерв'ю, націленим на виявлення схильності лю-дини до агресивних форм поведінки як у вербальному, так у фізичному її проявах $(<1>)$. Тест (АП) складається з 40 тверджень, яким співпадає діхотомічна шкала відповідей. Методика дозволяє дослідити психологічні особливості респондента за 4 шкалами: схильність до прямої вербальної агресії (ПВ), схильність до непрямої агреciї (НB), схильність до прямої фізичної агресії (ПФ), схильність до непрямої фізичної агресії (НФ), а також за інтегральним показником - рівнем нестриманості (PH).

Методика «Самооцінка тривожності, ригідності та екстравертованості» (Д. Моудслі), чи тест «ТРЕ», $\epsilon$ структурованим психологічним інтерв'ю, націленим на експрес-діагностичне оцінювання трьох важливих характеристик індивіда: тривожності, ригідності та екстравертованості $(<2>)$. Тест (ТРЕ) скла-дається з 40 запитань, якім співпадає діхотомічна шкала відповідей. Кожній, зазначеній у назві методики, психологічній характеристиці співпадає відпо-відна шкала з структурно можливим результатом від 20 до 80 балів.

«IPC-Fragebogen», який в россійськовмовній науковій літературі часто позначається як «Опитувальник локусу контролю» (H. Levenson) є структурованим психологічним інтерв'ю, націленим на експрес-діагностику таких важливих харктеристик, як інтерналність та екстернальність $(<3>)$. Згідно до теоретичних постулатів, якими користувалися розробники методики, минулі досвіди індивіда та генералізовані очікування, накопичені в інших ситуаціях, призводять до набуття стійкої схильності до класифікації усіх подій навколишнього на грунті сприйнятих причин отримання підкріплення, тобто саме «локусу контролю». Ця особистісна якість певною мірою дає можливість прогнозувати реагування респондента в складних умовах. Тест «IPC-Fragebogen» складається з 24 тверджень 3 діхотомічною шкалою відповідей. Аналіз отриманих результатів здійснюється за трьома шкалами: інтернальності (I), екстернальності за рахунок випадку (C) та екстернальності за рахунок людей $(\mathrm{P})$.

Міссісіпська шкала ПТСР (N. M. Keane) є структурованим психологічним інтерв'ю, спрямованим на експрес-діагностику наявності та вираженості симптомів посттравматичного стресового розладу, що особливо важливо під час обстеження контингенту працівників OBC, які приймали участь у бойових діях, у припиненні масових заворушень чи у інших екстремальних ситуаціях $(<4>;<5>)$. Опитувальник (MS PTSD) складається з 35 тверджень, кожне з яких респондент може оцінити за шкалою Лайкерта з 5 ступенями відповідності, а результати аналізуються за сумою показників двох шкал («пряма» та «зворотна»).

Статистична обробка отриманих результатів здійснювалась з використанням розрахунку коефіцієнтів $\alpha$ Л. Кронбаха, половинного розщеплення Гуттмана, $\delta$ - 
Л. Фергюсона, діхотомічної кореляції , однофакторного дисперсійного аналізу з використанням класичної моделі Фішера, патріціонного кластерного аналізу та експлораторного факторного аналізу.

Група обстежених складалась з 348 працівників органів та підрозділів внутрішніх справ (Табл. 1) у віці від 21 до 48 років, при чому 185 осіб $(53,2 \%)$ були у віці до 30 років, а 163 особи $(46,8 \%)$ - старіші за 30 років. Усі $100 \%$ респондентів були представниками чоловічого гендеру, які по службі характеризувалися позитивно, за психіатричною допомогою ніколи не зверталися, інформації про епізоди відхилень від загальноприйнятих форм поведінки не надходило, за результатами психіатричного огляду будь-яких розладів психіки та поведінки діагностовано не було.

Стаж служби респондентів у ОВС становив від 1 до 27 років, при цьому 77 респондентів $(22,1 \%)$ мали стаж служби менш, ніж 3 роки, 123 респонден-ти $(35,4 \%)-$ від 3 до 10 років, а 148 респондентів (42,5\%) - більш, ніж 10 років.

Обстежувана вибірка працівників ОВС була складена методом випадкового вибору та складалася з представників практично усіх основних поліцейських професій (1), які були згруповані за напрямками службової діяльності: працівники спецпідрозділів ( Грифон» та ін.) - 68 осіб (19,54\%), працівники патрульної служби поліції - 120 осіб (34,48\%), оперуповноважені та їх помічники (Управління карного розшуку, Управління по боротьбі з незаконним обігом наркотиків, тощо) - 76 осіб $(21,84 \%)$, дільничні інспектори - 31 особа $(9,91 \%)$ та працівники, які працюють на неоперативних посадах (слідчі, працівники кадрового апарату, експертикриміналісти, тощо) - 53 особи $(15,23 \%)$.

Кількість офіцерів складала 183 особи $(52,6 \%)$, а кількість сержантів та прапорщиків - 165 осіб $(47,4 \%)$. 221 респондент (63,5\%) мав вищу освіту, а $127(36,5 \%)$ - середню або середню-спеціальну. Більшість респондентів знаходились у шлюбі чи були неодружені (189 осіб $(54,3 \%)$ та 143 особи $(41,1 \%)$ відповідно), і лише 16 осіб (4,6\%) були розлучені. Практично порівну вибірка розділялася на респондентів, які мали на вихованні дітей та їх не мали $(165$ осіб $(47,4 \%)$ та 183 особи $(52,6 \%)$ відповідно).

Таким чином, за своїм обсягом та соціологічними характеристиками дослідницька група $є$ репрезентативною по відношенню до загального контингенту працівників OBC та може бути використана для проведення апробації психодіагностичних методик і формування висновків про їх надійність, дискримінативність та валідність в межах цього специфічного контингенту.

\section{3. Результати}

\section{1. Надійність психометричних методик}

Надійність тестів була досліджена шляхом визначення їх консистентності за результатами розрахунку ко- ефіцієнту $\alpha$ Л. Кронбаха та методом розщеплення навпіл. За результатами оцінювання консістентності тесту «Агресивна поведінка» були отримані дані, які свідчать про досить високу внутрішню узгодженість складових інтегрального показника РН, та прийнятну консістентність шкал КВ та ПФ, тоді як показники коефіцієнтів $\alpha$-Кронбаха та половинного розщеплення Гуттмана для шкал ПВ та КФ вказують на сумнівний характер надійності цих шкал (Табл. 2 .

За результатами аналізу показників методики «Самооцінка тривожності, ригідності та екстравертованості». було виявлено, що середні інтегральні показники тривожності, ригідності та екстравертованості обстежуваного контингенту знаходились в межах середнього рівня. Разом з тим, слід зазначити, що показники коефіцієнтів $\alpha$-Кронбаха та половинного розщеплення Гуттмана для діагностичних шкал цього тесту були вкрай низькими. Таким чином, від $44 \%$ до $86 \%$ дисперсії результатів, отриманих за шкалами тесту, залежать не від справжньої дисперсії, а від дисперсії помилки, що дає можливість розцінювати надійність методики «Самооцінка тривожності, ригідності та «екстравертованості» як незадовільну.

За результатами проведеного дослідження показників методики «IPC-Fragebogen» було встановлено, що консістентність зазначеного тесту також не $є$ достатньою, а від $46 \%$ до $61 \%$ дисперсії отриманих результатів залежать від дисперсії помилки (Табл. 3).

За результатами оцінювання консістентності тесту «MS PTSD» були отримані дані, які свідчать про досить високу внутрішню узгодженість методики. Крім того, отримані в результаті нашого дослідження дані збігаються з результатами вивчення консістентності, в особливості - показника $\alpha$-Кронбаха, які були отримані на аналогічному матеріалі авторами російськомовної адаптації цієї методики ( $<4>$ ), хоча середній показник шкали у російських поліцейських і був декілька більшим (Табл. 3).

\section{2. Дискримінативність та валідність методик}

Дискримінативність використаних психодіагностичних методик оцінювалась шляхом розрахунку коефіцієнту $\delta$ Л.Фергюсона. В результаті проведеного аналізу було встановлено, що дискримінативність усіх шкал методик «AП», «MS PTSD», «TPE» та «IPCFragebogen», $є$ досить високою $(\delta$-Ferguson $=0,880,1)$, причому найвищий рівень дискримінативності виявили показники методики «MS PTSD» та «Агресивна поведінка», а показники ін-дивідуальної прогностичності тестів «ТPE» та «IPC-Fragebogen» були значно меншими (Табл. 4 ).

Конструктивна валідність психодіагностичних методик досліджувалась шляхом проведення експлораторного факторного аналізу, причому факторне навантаження, рівне чи вище за 0,3 , розцінювалось як достатнє, за умовою, що інші факторні навантаження за відповідним пунктом прагнули до нуля. 


\begin{tabular}{|c|c|c|}
\hline Соціологічні характеристики & Кількість осіб & $\%$ \\
\hline \multicolumn{3}{|c|}{ Напрямок службової діяльності } \\
\hline спецпідрозділи & 68 & 19.54 \\
\hline патрульна служба & 120 & 34.48 \\
\hline оперативна служба & 76 & 21.84 \\
\hline дільничні інспектори & 31 & 8.908 \\
\hline неоперативна служба & 53 & 15.23 \\
\hline спецпідрозділи & 68 & 19.54 \\
\hline \multicolumn{3}{|l|}{ Звання } \\
\hline офіцер & 183 & 52.59 \\
\hline сержант, прапорщик & 165 & 47.41 \\
\hline \multicolumn{3}{|l|}{ Освіта } \\
\hline вища & 221 & 63.5 \\
\hline середня & 127 & 36.5 \\
\hline \multicolumn{3}{|c|}{ Сімейний стан } \\
\hline одружений & 189 & 54.31 \\
\hline неодружений & 143 & 41.09 \\
\hline розлучений & 16 & 4.598 \\
\hline \multicolumn{3}{|c|}{ Діти у родині } \\
\hline мають & 165 & 47.41 \\
\hline не мають & 183 & 52.59 \\
\hline
\end{tabular}

Табл. 2: Загальні статистичні характеристики показників методики «Агресивна поведінка» (Є.П. Ільїн) та результати розрахунку статистичних характеристик її консистентності.

\begin{tabular}{|c|c|c|c|c|c|}
\hline Шкали & ПВ & КВ & КФ & ПФ & РН \\
\hline \hline M & 3.368 & 3.052 & 1.181 & 3.141 & 9.56 \\
\hline SE & 0.094 & 0.101 & 0.072 & 0.098 & 0.228 \\
\hline SD & 1.753 & 1.89 & 1.338 & 1.832 & 4.251 \\
\hline D & 3.075 & 3.571 & 1.791 & 3.355 & 18.07 \\
\hline$\alpha$-Kронбаха & 0.567 & 0.607 & 0.536 & 0.605 & 0.78 \\
\hline Guttman split-half & 0.567 & 0.676 & 0.407 & 0.522 & 0.763 \\
\hline \hline
\end{tabular}

M - середнє за шкалою; SE - стандартна помилка за шкалою; SD - стандартне відхилення за шкалою; D - дисперсія показників шкали; $\alpha$-Кронбаха - коефіцієнт альфа Л. Кронбаха; Guttman split-half - коефiцiєнт половинного розщеплення Гуттмана.

В результаті проведеного аналізу показників окремих пунктів методики «Агресивна поведінка» було виділено 4 фактори, які теоретично повинні були співпадати 3 діагностичними шкалами методики. Відповідно до виділених факторів їх навантаження було достатнім та максимальним для наступних змінних тесту (Табл. 5): 1 фактор - змінні № 2, 5, 9, 13, 25, 26, 30, 37 та $38 ; 2$ фактор - змінні № 1, 6, 11, 14, 15, 16, 17, 18, 21, $27,29,31,34$ та $35 ; 3$ фактор - змінні № $3,11,19,22$, 23, 24 та 25; 4 фактор - змінні № 4, 8, 12, 20, 28 та 36. Крім того, змінні № 32, 33, 39 та 40 мали факторне навантаження нижче за 0,3 відповідно до будь-якого 3 виділених факторів. В результаті порівняння виявлених факторів та наборів пунктів тесту, які їх сформували, зі структурою запропонованих авторами методики діагностичних шкал, було виявлено, що конструктив- на валідність шкали ПВ була підтверджена тільки для $50 \%$ тверджень, які їі складають; для шкали КВ - для $30 \%$ тверджень; для шкали КФ - для $30 \%$ тверджень; для шкали ПФ - для $60 \%$ тверджень.

Все вищесказане вказує на недостатні зв'язки між латентними факторами та змінними, що спостерігаються, тобто на недостатню конструктивну валідність методики «Агресивна поведінка».

В результаті проведеного експлораторного факторного аналізу показників окремих пунктів методики «Опитувальник локусу контролю» було виділено 3 фактори, які теоретично повинні були співпадати з діагностичними шкалами методики (Табл. 6). Разом з тим, в при оцінюванні показників факто-рного навантаження змінних було встановлено, що 1 фактору відповідали змінні №2, 6, 7, 10, 14, 16, 24, які становили повний 
Psychosomatic Medicine and General Practice • Sep $2016 \bullet$ Vol.1(1) • e010105

Табл. 3: Загальні статистичні характеристики та результати розрахунку консистентності тестів «TPE», «IPC-Fragebogen» та «MS PTSD»

\begin{tabular}{|c|c|c|c|c|c|c|c|c|}
\hline Методики & \multicolumn{3}{|c|}{ TPE } & \multicolumn{3}{c|}{ I-P-C Frageboden } & \multicolumn{2}{c|}{ MS PTSD } \\
\hline \hline Шкали & $\mathrm{T}$ & $\mathrm{P}$ & $\mathrm{E}$ & $\mathrm{I}$ & $\mathrm{P}$ & $\mathrm{C}$ & MBC України & МВC РФ \\
\hline $\mathrm{M}$ & 36.7 & 42 & 34.22 & 6.95 & 1.08 & 1.8 & 48.56 & 64.65 \\
\hline $\mathrm{SE}$ & 0.4 & 0.41 & 0.42 & 0.06 & 0.07 & 0.08 & 0.53 & - \\
\hline $\mathrm{SD}$ & 6.69 & 7.61 & 7.8 & 1.1 & 1.27 & 1.45 & 10.06 & - \\
\hline $\mathrm{D}$ & 44.8 & 57.8 & 60.8 & 1.21 & 1.62 & 2.1 & 101.18 & - \\
\hline$\alpha$-Кронбаха & 0.46 & 0.14 & 0.44 & 0.39 & 0.58 & 0.54 & 0.67 & 0.69 \\
\hline Guttman split-half & 0.49 & 0.13 & 0.56 & 0.36 & 0.59 & 0.44 & 0.63 & 0.78 \\
\hline \hline
\end{tabular}

M - середнє за шкалою; SE - стандартна помилка за шкалою; SD - стандартне відхилення за шкалою; D - дисперсія показників шкали; $\alpha$-Кронбаха - коефіцієнт альфа Л. Кронбаха; Guttman split-half - коефіцієнт половинного розщеплення Гуттмана.

Табл. 4: Результати розрахунку коефіцієнту дискримінативності $\delta$-Фергюсона психодіагностичних методик «AП», «MS PTSD», «TPE» та «I-P-C-Fragebogen».

\begin{tabular}{|c|c|c|c|c|c|c|}
\hline Методика & \multicolumn{5}{|c|}{ «Агресивна поведінка» } & MS \\
\hline шкала & ПВ & KB & $\mathrm{K} \Phi$ & ПФ & $\mathrm{PH}$ & PTSD \\
\hline$\delta$-Ferguson & 0.922 & 0.938 & 0.794 & 0.921 & 0.963 & 0.984 \\
\hline Методика & \multicolumn{3}{|c|}{ 《TPE» } & \multicolumn{3}{|c|}{ «I-P-C-Fragebogen» } \\
\hline шкала & $\mathrm{T}$ & $\mathrm{P}$ & $\mathrm{E}$ & $\mathrm{I}$ & $\mathrm{P}$ & $\mathrm{C}$ \\
\hline$\delta$-Ferguson & 0.894 & 0.805 & 0.833 & 0.781 & 0.805 & 0.873 \\
\hline
\end{tabular}

M - середнє за шкалою; SE - стандартна помилка за шкалою; SD - стандартне відхилення за шкалою; D - дисперсія показників шкали; $\alpha$-Кронбаха - коефіцієнт альфа Л. Кронбаха; Guttman split-half - коефіцієнт половинного розщеплення Гуттмана.

набір пунктів шкали С, але, крім того, найбільші факторні навантаження в межах цього виділеного фактору мали змінні № $3,8,11,13,17$ та 22 , тобто усі пункти шкали Р, за виключенням 15 та 20.

Другому фактору відповідали змінні №1, 5, 9, 21 та 23 , які співпадали з пунктами шкали I, а також змінні № 15 та 20, які співпадали з пунктами шкали Р. Найбільші факторні навантаження змінних №18 та 19, які співпадали відповідним пунктам шкали I, були віднесені до окремого 3 фактору.

\section{4. Обговорення}

Таким чином, хоча факторизація, яка була проведена 3 використанням результатів емпіричного дослідження і не підтвердила конструктивну валідність методики «Опитувальник локусу контролю» для контингенту працівників ОВС, отримані результати не протирічать загальному теоретичному базису, на якому був заснований опитувальник - виділений нами 1 фактор включав в себе пункти двох шкал, які оцінювали одну й ту ж психологічну характеристику - екстернальність (тільки в різних її проявах), не включаючи в себе жодного пункту шкали, яка оцінювала протилежну психологічну ха-рактеристику - інтернальність.

В результаті проведеного експлораторного факторного аналізу показників окремих пунктів методики
«Самооцінка тривожності, ригідності та екстравертованості» було виявлено, що у випадку виділення 3 факторів, які теоретично повинні були співпадати 3 діагностичними шкалами тесту, достатні факторні навантаження мають тільки 25 з 35 змінних методики, тобто у $29 \%$ отриманих змінних статистично значущі зв'язки з латентними факторами були відсутні (Табл.6). Крім того, будь-якого збігу структури змінних, що сформували виділені фактори зі структурою діагностичних шкал методики не спостерігалося: 1 фактор містив 6 змінних, які входили до структури шкали Т та 6 змінних, які входили до шкали Е; 2 фактор - 2 змінних, які входили до шкали $\mathrm{P}$ та по 1 змінній, які входили до шкал Т та E; 3 фактор - 3 змінних, які входили до шкали Т та 1 змінну, яка входила до шкали Е. Таким чином, отримані результати свідчать про недостатню конструктивну валідність методики «Самооцінка тривожності, ригідності та екстравертованості».

Критеріальна валидність психодіагностичних методик досліджувалась шляхом розрахунку коефіцієнту діхотомічної кореляції . Статистична значущість коефіцієнту визначалася по таблицям розподілу 2 з одним ступенем свободи. Для здійснення вказаного аналізу була проведена кластерізація показників психодіагностичних методик методом K-середніх, що дозволило виділити групи респондентів (p0,0001), які мали статистично значущі більш за середньогрупові (1 кластер) 
Psychosomatic Medicine and General Practice • Sep $2016 \bullet$ Vol.1(1) • e010105

Табл. 5: Результати експлораторного факторного аналізу методики «Агресивна поведінка» (варімакс - кручення 3 нормалізацією Кайзера).

\begin{tabular}{|c|c|c|c|c|c|c|c|c|c|}
\hline \multirow[t]{2}{*}{ Змінна } & \multicolumn{4}{|c|}{ Матриця повернутих компонентів } & \multirow[t]{2}{*}{ Змінна } & \multicolumn{4}{|c|}{ Матриця повернутих компонентів } \\
\hline & 1 & 2 & 3 & 4 & & 1 & 2 & 3 & 4 \\
\hline 1 & 0.107 & 0.461 & 0.026 & 0.081 & 21 & 0.279 & 0.396 & 0.126 & 0.139 \\
\hline 2 & 0.622 & 0.045 & 0.15 & 0.164 & 22 & 0.214 & 0.125 & 0.456 & 0.211 \\
\hline 3 & 0.18 & 0.14 & 0.431 & 0.011 & 23 & 0.02 & 0.172 & 0.423 & 0.022 \\
\hline 4 & 0.143 & 0.08 & 0.03 & 0.477 & 24 & 0.071 & 0.06 & 0.525 & 0.165 \\
\hline 5 & 0.424 & 0.086 & 0.05 & 0.056 & 25 & 0.339 & 0.09 & 0.547 & 0.157 \\
\hline 6 & 0.339 & 0.348 & 0.089 & 0.013 & 26 & 0.555 & 0.14 & 0.13 & 0.155 \\
\hline 7 & 0.03 & 0.261 & 0.147 & 0.159 & 27 & 0.11 & 0.629 & 0.117 & 0.105 \\
\hline 8 & 0.284 & 0.208 & 0.177 & 0.449 & 28 & 0.261 & 0.2 & 0.14 & 0.412 \\
\hline 9 & 0.463 & 0.037 & 0.041 & 0.195 & 29 & 0.191 & 0.32 & 0.06 & 0.229 \\
\hline 10 & 0.108 & 0.198 & 0.25 & 0.243 & 30 & 0.546 & 0.116 & 0.09 & 0.098 \\
\hline 11 & 0.074 & 0.337 & 0.359 & 0.222 & 31 & 0.2 & 0.376 & 0.274 & 0.014 \\
\hline 12 & 0.228 & 0.237 & 0.127 & 0.308 & 32 & 0.131 & 0.177 & 0.149 & 0.282 \\
\hline 13 & 0.478 & 0.177 & 0.243 & 0.12 & 33 & 0.122 & 0.021 & 0.59 & 0.19 \\
\hline 14 & 0.17 & 0.466 & 0.04 & 0.09 & 34 & 0.058 & 0.612 & 0.02 & 0.111 \\
\hline 15 & 0.079 & 0.585 & 0.09 & 0.15 & 35 & 0.217 & 0.371 & 0.16 & -0.073 \\
\hline 16 & 0.09 & 0.323 & 0.114 & 0.58 & 36 & 0.17 & 0.073 & 0.27 & 0.642 \\
\hline 17 & 0.02 & 0.449 & 0.08 & 0.137 & 37 & 0.6 & 0.02 & 0.068 & 0.14 \\
\hline 18 & 0.323 & 0.307 & 0.02 & -0.04 & 38 & 0.328 & 0.254 & 0.057 & 0.004 \\
\hline 19 & 0.028 & 0.06 & 0.582 & 0.028 & 39 & 0.13 & 0.018 & 0.246 & 0.03 \\
\hline 20 & 0.415 & 0.082 & 0.066 & 0.355 & 40 & 0.18 & 0.021 & 0.043 & 0.094 \\
\hline
\end{tabular}

M - середнє за шкалою; SE - стандартна помилка за шкалою; SD - стандартне відхилення за шкалою; D - дисперсія показників шкали; $\alpha$-Кронбаха - коефіцієнт альфа Л. Кронбаха; Guttman split-half - коефіцієнт половинного розщеплення Гуттмана.

та менш за середньогрупові (2 кластер) показники за кожною окремою методикою. Кількість респондентів, які склали зазначені кластери колихалась від 71 до 230 осіб. Виключенням стала шкала ригідності методики «ТРЕ», кластерізація показників якої виявилася статистично неприйнятною $(\mathrm{p}=0,097)$.

В якості критеріальної групи були обрані особи, які склали 1 кластер за результатами методики MS PTSD. В основу такого вибору було покладено те, що дана методика за своєю структурою комплексно оцінює (прямо чи непрямо) і симптоми тривоги, і прояви емоційної ригідності, і схильність до агресивних проявів, і інші психологічні маркери, які свідчать про порушення психологічної адаптації. Крім того, як вже було вказане вище, ця методика вже проходила адаптацію на контингенті МВС Російської Федерації, до того ж їі консистентність, дискримінативність та конструктивна валідність були повністю підтверджені протягом нашого дослідження.

В результаті проведеного розрахунку коефіцієнту було встановлено, що при досить високому рівні статистичної значущості отриманих результатів критеріальну валідність усіх психодіагностичних методик можливо вважати за достатню: для методики «Агресивна поведінка»: $=0,242 ; \mathrm{p}=6 \mathrm{E}-06$; для методики «Самооцінка тривожності, ригідності та екстравертованості»:
$=0,225 ; \mathrm{p}=3 \mathrm{E}-05$; для методики «Опитувальник локусу контролю»: $=0,354 ; \mathrm{p}=4 \mathrm{E}-11$.

\section{5. Висновки}

Таким чином, в результаті проведеного аналізу основних показників якісного оцінювання психометричних характеристик обраних експериментальнопсихологічних методик були отримані дані, які дають можливість стверджувати, що для використання в межах контингенту працівників ОВС надійність методики «Агресивна поведінка» $є$ досить високою тільки відносно діагностики загального рівня нестриманості, але надійність та конструктивна валідність їі окремих шкал недостатні. Приймаючи до уваги високий рівень дискримінативності та критеріальної валідності цього тесту, методика «Агресивна поведінка» може бути використана, але тільки як індикатор загального рівня нестриманості працівників ОВС, тоді як її використання з метою вивчення структури агресивної поведінки не може бути розцінене як доцільне.

Міссісіпська шкала ПТСР виявила високий рівень надійності, дискримі-нативності та валідності, що дає можливість рекомендувати їі використання в процесі психодіагностичного обстеження працівників ОВС. 
Psychosomatic Medicine and General Practice • Sep $2016 \bullet$ Vol.1(1) • e010105

Табл. 6: Результати експлораторного факторного аналізу методик «Опитувальник локусу контролю» та «ТРЕ» (варімакс - кручення з нормалізацією Кайзера).

\begin{tabular}{|c|c|c|c|c|c|c|c|}
\hline \multirow[t]{2}{*}{ Змінна } & \multicolumn{3}{|c|}{ Матриця повернутих компонентів } & \multirow[t]{2}{*}{ Змінна } & \multicolumn{3}{|c|}{ Матриця повернутих компонентів } \\
\hline & 1 & 2 & 3 & & 1 & 2 & 3 \\
\hline \multicolumn{8}{|c|}{ «Опитувальник локусу контролю» } \\
\hline 1 & -0.11 & 0.42 & -0.23 & 13 & 0.46 & -0.05 & 0.11 \\
\hline 2 & 0.42 & 0.05 & -0.07 & 14 & 0.58 & -0.21 & -0.01 \\
\hline 3 & 0.61 & -0.22 & -0.02 & 15 & 0.28 & 0.38 & 0.25 \\
\hline 4 & -0.16 & 0.1 & 0.11 & 16 & 0.56 & 0.16 & -0.09 \\
\hline 5 & -0.2 & 0.35 & 0.14 & 17 & 0.41 & 0.17 & -0.12 \\
\hline 6 & 0.5 & -0.15 & 0.12 & 18 & -0.09 & 0.02 & 0.82 \\
\hline 7 & 0.47 & -0.24 & -0.14 & 19 & -0.13 & 0.08 & 0.81 \\
\hline 8 & 0.39 & -0.02 & -0.14 & 20 & 0.29 & 0.38 & -0.12 \\
\hline 9 & 0.06 & 0.52 & -0.01 & 21 & -0.16 & 0.59 & 0.07 \\
\hline 10 & 0.36 & 0.2 & 0.18 & 22 & 0.56 & 0.13 & -0.17 \\
\hline 11 & 0.56 & -0.07 & -0.16 & 23 & -0.12 & 0.46 & 0.11 \\
\hline 12 & 0.5 & -0.14 & -0.07 & 24 & 0.49 & -0.07 & 0.11 \\
\hline \multicolumn{8}{|c|}{ «Самооцінка тривожності, ригідності та екстравертованості» } \\
\hline 1 & 0.577 & -0.129 & -0.186 & 19 & 0.362 & -0.013 & 0.07 \\
\hline 2 & 0.538 & -0.072 & -0.153 & 20 & 0.419 & -0.231 & 0.162 \\
\hline 3 & -0.232 & -0.038 & -0.033 & 21 & 0.406 & 0.131 & 0.232 \\
\hline 4 & -0.044 & -0.113 & 0.283 & 22 & 0.244 & 0.051 & -0.307 \\
\hline 5 & -0.104 & 0.133 & 0.4 & 23 & 0.523 & 0.036 & 0.217 \\
\hline 6 & 0.525 & -0.026 & 0.022 & 24 & -0.015 & -0.26 & 0.137 \\
\hline 7 & -0.059 & 0.219 & -0.09 & 25 & 0.274 & -0.118 & 0.528 \\
\hline 8 & -0.182 & -0.178 & 0.316 & 26 & 0.372 & 0.057 & -0.027 \\
\hline 9 & 0.181 & -0.571 & 0.002 & 27 & 0.262 & -0.579 & 0.087 \\
\hline 10 & 0.216 & -0.054 & 0.611 & 28 & 0.191 & 0.451 & -0.098 \\
\hline 11 & 0.401 & -0.15 & -0.24 & 29 & 0.446 & -0.004 & -0.039 \\
\hline 12 & -0.075 & 0.366 & 0.119 & 30 & 0.154 & 0.447 & -0.092 \\
\hline 13 & 0.457 & -0.076 & 0.031 & 31 & 0.444 & -0.199 & 0.137 \\
\hline 14 & 0.068 & 0.317 & 0.063 & 32 & 0.323 & 0.423 & 0.097 \\
\hline 15 & 0.428 & -0.181 & -0.02 & 33 & 0.444 & 0.132 & -0.113 \\
\hline 16 & 0.436 & 0.06 & 0.036 & 34 & 0.192 & -0.096 & 0.55 \\
\hline 17 & -0.041 & 0.203 & 0.317 & 35 & 0.054 & 0.372 & 0.324 \\
\hline 18 & 0.499 & 0.055 & -0.222 & & & & \\
\hline
\end{tabular}

Рівень надійності та конструктивної валідності методики «Самооцінка тривожності, ригідності та екстравертованості» виявився низьким. Крім того, надійність «Опитувальника локус контролю» також виявилася недостатньою, а її конструктивна валідність обмежена виявленням переваги інтернальних-екстернальних властивостей, що хоча і не суперечить концепції Дж. Роттера, не співпадає повністю з характеристиками тесту, запропонованими його авторами. Все вищесказане вказує на неможливість використання цих тестів в процесі психологічного обстеження працівників ОВС.

Підводячи підсумок, слід звернути особливу увагу на ще один висновок, якій логічно витікає з усього вищесказаного. Існуюча практика впровадження в роботу відомчих психолого-психіатричних служб психодіагностичних методик, навіть тих, які добре зарекомендува- ли себе протягом довготривалого використання в межах інших професійних контингентів, без проведення їх якісного оцінювання та аналізу результатів апробації при обстеженні пра-цівників ОВС слід вважати неприйнятною. Навпроти, використання будь-яких психодіагностичних інструментів відносно представників цього досить специфічного контингенту повинно відбуватися тільки після обгрунтованого доказу їх надійності та валідності з урахуванням гендерних, соціальнопсихологічних, а можливо і регіональних особливостей контингенту.

\section{References}

1. Ilyin E. Emotsii i chuvstva. Saint Petersburg: Pyter; 2001.

2. Dermanova I. Diagnostika emotsionalno-nravstvennogo razvitiya. Saint Petersburg: Pyter; 2002. 
3. Krampen G. Zur spezialitat von kontrolluberzeugungen. Psychology Schweizerische Zeitschrift fur Psychologie 1986;1(12):67-86.

4. Tarabrina N. Praktikum po psihologii posttravmaticheskogo stressa. Saint Petersburg: Pyter; 2001.

5. Omelianovich V. Post-Traumatic Stress Disorder with Operative Staff of Internal Affairs Bodies (Early Diagnostics and Psychoprofillaxis). Kharkov; 2003 